\title{
Level of Student Social Skills Achievement on Adolescence
}

\author{
Mutiani \\ Social Studies Education \\ Faculty of Teacher Training and Education \\ Universitas Lambung Mangkurat \\ Banjarmasin, Indonesia \\ mutiani@ulm.ac.id
}

\author{
Ndaru Mukti Oktaviani, Panji Rizalul Fatah \\ Primary School Teacher Education \\ Kuningan University \\ Banjarmasin, Indonesia \\ oktaviani.ndarumukti@gmail.com,prizalu109@gmail.com
}

\begin{abstract}
The purpose of this study was to determine the extent of the achievement of students' social skills in adolescent times. The type of research that will be used is survey research. The research subjects were students of PGSD at the University of Kuningan. The research method used in this research is a quantitative method. Data collection will be carried out using questionnaire techniques and interviews. The purpose of this study is to know the achievement of students' social skills comprehensively in adolescent times. The survey approach used in this study refers to the steps of the survey research proposed by Rea and Parker namely; (1) The research schedule and budget, (3) establishment of information based, (4) The sampling frame, (5) Determination of sample size and sample selection , (6) design of the survey instrument, (7) pretest of survey instrument, (8) selection and interview training, (9) implementation of the survey, (10) codification of the completed questionnaires and computerized data entry, and (11) data analysis and final report. The sampling technique used in this study uses random purposive sampling. The results showed the percentage of aspects of peer relations amounted to $66.63 \%$, aspects of selfmanagement amounted to $76.86 \%$, academic elements which had the highest percentage of $82.95 \%$, aspects of compliance reached $67.91 \%$, and assertion aspects were at number $52.48 \%$. The overall percentage of the four aspects of social skills of the students of the University of Kuningan PGSD is in the good category with a percentage of $69.96 \%$. The results of the study have an impact on the need to improve the management of the academic situation of the campus to establish the social skills of students of the FKIP Primary School Teacher Education Study Program.
\end{abstract}

Keywords—-social skills; adolescent

\section{INTRODUCTION}

Life in the 21 st century experienced many changes from the previous century. In line with what was put forward by Ref [1] that "the world has changed so fundamentally in the last few decides that the roles of learning and education in day-to-day living have also changed forever." That in every decade, life will always experience change. Good quality human resources are needed to deal with challenges in the 21 st century so that every human being is required to be able to have the ability to face challenges nowadays.
The term humanizing human being becomes a term that is relevant to every individual human being who is required to have good self-ability, both from the intellectual aspect, attitude, and skills. All these aspects can be obtained through education. Education is an effort made to awaken the potential that exists within humans [2]. This shows that with education, humans can have and develop their potential to be able to compete and be able to face various challenges and problems they face in their daily lives.

Social skills are the skills to maintain relationships by building networks based on the ability to find common ground and build good relationships [3]. Ref [3] opinion illustrates that social skills individuals will be able to establish good communication with other individuals. This is needed by every individual, especially students who are pursuing higher education, wherein individual colleges are required to be able to communicate to build knowledge as a whole.

Social skills are skills that need to be owned by everyone because these skills are part of life skills. Life skills can lead a person to achieve success in his social life in society. Social skills have a function as a means to obtain good relationships in interacting with others; example: preserving the environment, helping others, working together, making decisions, communicating, entrepreneurship, and participation. The development of social values and skills is something that must be achieved by educators. This is because students are social beings who will live in a society [4]. Social skills possessed include 1) Living and working together; taking turns, respecting the rights of others; being socially sensitive, 2) Learning self-control and self-direction, and 3) Sharing ideas and experience with others [5].

The existence of social skills, students will be able to interact well with their peers, family, and social environment. The development of social skills is also related to students 'cognitive because the output or results of students' cognitive relation to social skills will be seen from the behavior of students in the social environment. Social skills have an impact on the level of success if individuals have problems with social skills, individuals tend to be weak in academic achievement. 
This research is a form of collaboration between the two institutions. However, in particular, the investigation was presented to see the level of achievement of students of the Primary School Teacher Education Study Program at the Teacher Training and Education Faculty at Kuningan University in social skills. It is expected that this research can provide answers to the extent to which social skills possessed by Primary School Teacher Education Study Program students in the Teaching and Education Faculty at Kuningan University in building a network that enables students to prevent and overcome various problems related to social skills.

This research is included in the type of survey research with a quantitative descriptive approach. Survey research is research conducted to obtain data from certain natural (not artificial) places by circulating questionnaires, tests, structured interviews, etc. so that they can be used to make conclusions [6]. Survey research provides a quantitative or numeric description of trends, attitudes, or opinions of a population by studying a sample of that population. It includes cross-sectional and longitudinal studies using questionnaires or structured interviews for data collection - with the intent of generalizing from a sample to a population) [7].

Based on Fowler's opinion it can be said that survey research is a study that describes the number of habits, attitudes or opinions of the population by studying the sample. Survey research is included in cross-sectional and longitudinal. Survey research is done by using questionnaires or structured interviews to get data then the data is used to make conclusions or generalizations. To facilitate the research, researchers compile the following research plan chart:

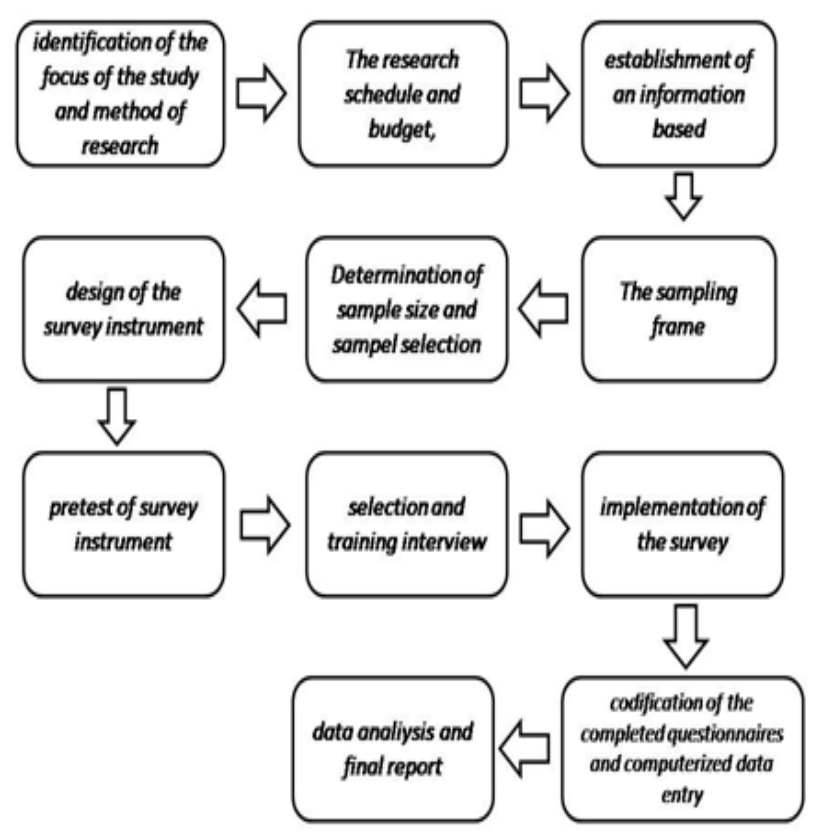

Fig. 1. Research Plan Chart

The population of this study was all students of the Primary School Teacher Education Study Program at the Teacher Training and Education Faculty at the University of Kuningan, and the samples of the research range were students of 2013, class of 2014, class of 2015, and class of 2016.

TABLE I. POPULATION AND SAMPLE OF PGSD-FKIP STUDENTS KUNINGAN UNIVERSITY

\begin{tabular}{|l|l|l|}
\hline \multicolumn{1}{|c|}{ Academic Year } & Population & Sample \\
\hline $2013-2014$ & 183 & 18 \\
\hline $2014-2015$ & 289 & 30 \\
\hline $2015-2016$ & 204 & 20 \\
\hline $2016-2017$ & 183 & 18 \\
\hline Total & 859 & 86 \\
\hline
\end{tabular}

\section{METHOD}

This chapter presents the general description of respondents, analyzes the results of the study, and discusses the results of the study. Respondents are 2017, 2016, 2015 and 2014 batch students from the PGSD Study Program FKIP Kuningan University in Kuningan District. The number of research subjects was taken using purposive sampling method. The following are the total respondents of PGSD FKIP students in the form of tables.

TABLE II. TOTAL RESPONDENTS PGSD FKIP STUDENTS OF KUNINGAN UNIVERSITY

\begin{tabular}{|l|l|l|}
\hline Level & Frequency & Percentage (\%) \\
\hline I & 12 & 13.95 \\
\hline II & 12 & 23.26 \\
\hline III & 20 & 23.26 \\
\hline V & 34 & 39.53 \\
\hline Total & 86 & 100 \\
\hline
\end{tabular}

\section{Result AND Discussion}

Research on the achievement of students' social skills in the adolescent period held by students of PGSD FKIP Kuningan University from 21 classes using closed questionnaires obtained the following results.

The following is the percentage of every aspect of social skills of PGSD students of FKIP at the University of Kuningan as a whole.

TABlE III. Percentage of Every Aspect of Student Social Skills IN THE ADOLESCENT PERIOD

\begin{tabular}{|l|l|l|l|}
\hline \multicolumn{1}{|c|}{ Aspects } & Answers Score & Percentage (\%) & Category \\
\hline Peer-relation & 2.865 & $66.63 \%$ & Good \\
\hline Self-management & 1.322 & $76.86 \%$ & Very Good \\
\hline Academic & 1.848 & $85.95 \%$ & Very Good \\
\hline Compliance & 876 & $67.91 \%$ & Good \\
\hline Assertion & 677 & $52.48 \%$ & Poor \\
\hline Total & 7588 & 69.96 & Good \\
\hline
\end{tabular}

Based on Table 3 obtained the percentage results for (peerrelation) of $66.63 \%$ with good category, self-management of $76.86 \%$ with the very good category, academic of $85.9 \%$ with the very good category, compliance of $67.91 \%$, and assertion of $52.4 \%$ percentage with good category. Based on the data in the table, the results show that the overall percentage of aspects of social skills of the University of Kuningan PGSD students is $69.96 \%$, this percentage shows that overall the social skills of 
the PGSD University Students of Kuningan are good. The following is the percentage of overall student social skills in the PGSD Study Program at Kuningan University in Kuningan District in the form of a diagram.

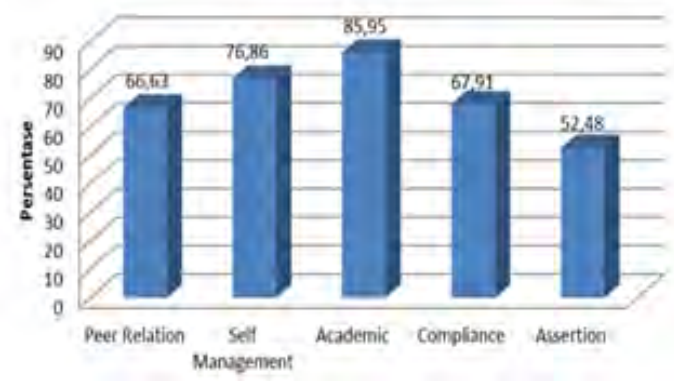

Fig. 2. Percentage of Student Social Skills

The following is the percentage of the level of social skills of the PGSD students at Kuningan University at each level.

TABle IV. Percentage of Social Skills of Students of PGSD in KUNINGAN UNIVERSITY

\begin{tabular}{|l|l|l|l|}
\hline Level & Answers Score & Percentage (\%) & Category \\
\hline I & 993 & $66.2 \%$ & Good \\
\hline II & 1796 & $70.76 \%$ & Good \\
\hline III & 1694 & $67.76 \%$ & Good \\
\hline IV & 3132 & $73.69 \%$ & Good \\
\hline Total & 7588 & $69.60 \%$ & Good \\
\hline
\end{tabular}

Based on the table above, the results of the percentage of social skills level of the PGSD students of Kuningan University in 2017 at level I, level II, level III and level IV are in the range of $50 \%-75 \%$ which means that the level of social skills of PGSD students in the University of Kuningan is in the category good. For more details, the level of social skills of PGSD students at the University of Kuningan can be seen in the following picture 3 :

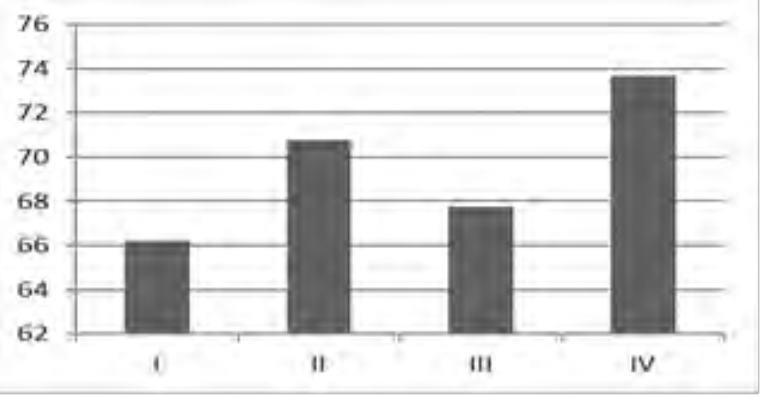

Fig. 3. Level of Student Social Skill

Based on the results of research that have been described in the previous sub-chapters, the following will be elaborated on some findings in the implementation of this research. The percentage level of achievement of students' social skills PGSD FKIP Kuningan University viewed from various aspects of the focus of the researcher, namely from the aspect or academic dimension which has the highest percentage of $82.95 \%$, and aspects of self-management by $76.86 \%$ are in the very good category. While the aspect of peer relations is $66.63 \%$, compliance aspect reaches $67.91 \%$, and assertion aspect is at $52.48 \%$. This means that the three aspects that exist in the study of the level of achievement of social skills of students of PGSD FKIP Kuningan University are categorized as good with detailed aspects consisting of aspects of peer relations, selfmanagement, compliance, and assertion including in the good category. The overall average of all aspects is at $69.96 \%$ with good categories.

Furthermore, the percentage level of achievement of social skills of PGSD students at the University of Kuningan are seen in various levels of being the respondents of the research, namely at level IV, the biggest percentage is $73.69 \%$, while at level I the percentage obtained is the smallest, which is $66.20 \%$, level III the percentage obtained was $67.76 \%$, and level II was $70.76 \%$. This means that the percentage level of achievement of social skills of PGSD students at Kuningan University at level I, level II, level III and level IV is in the range of $50 \%-75 \%$ which means that the level of achievement of social skills of PGSD students of FKIP Kuningan University is in the good category.

The percentage of peer relations dimensions or aspects of PGSD level IV students is the highest percentage of $71.24 \%$, followed by level II at $65.5 \%$, while level III is $63.60 \%$, and level $\mathrm{I}$ is $60.5 \%$. Overall, the average aspect or dimension of peer relations is $66.63 \%$. That is, the percentage of peer relations aspects of PGSD students at Kuningan University is in a good category. The high percentage of aspects of peer relations at level IV PGSD students is because respondents have been able to express empathy to other students. The emergence of a sense of empathy for students shows that students also have high social skills. The first characteristic of people having high social skills is empathy. Empathy means that an individual is full of understanding, tolerance, and caring for others. The high results of the survey were also evidenced by the results of interviews with MD respondents of IV level students who showed a sense of empathy for other students, namely when their friends had difficulty in carrying out tasks so that they got small grades, "By all means, as a human being I have a sense of empathy, namely wanting to move forward together, but on the other hand, my friend, who I invited to go forward, wanted to or not. Usually, I invite and remind him, and like that time I invited to do assignments together. "The results of this interview indicate that respondents have a good sense of empathy to other students, it is shown by the way MD invites and reminds his friends to do assignments and invites them to work on tasks together if they experience difficulties.

In contrast to the MD respondents of the fourth-grade students, PA, as a respondent, is a student of PGSD FKIP at Kuningan level I stated that he would help his friend who had difficulty if he did not have a dependent job or a lot of work. This was found by researchers when conducting interviews. The results of the discussion are as follows: "If there are friends who need help, I will help as best as possible without neglecting my assignments, communicating about the difficulties of friends and telling them about the responsibilities of my duties. If it can still be helped, not burdensome and does not interfere with my duties, I will immediately help." The interview result shows that students still need to consider their aspects that need to be prioritized. This is different from the 
fourth-year student MD respondents who gave considerable attention to their friends to be equally successful in their studies. It is seen that the attitude of understanding, tolerance and caring for fellow friends is high.

The percentage of the dimension or aspect of selfmanagement of the fourth year PGSD students is the largest percentage of $78.97 \%$, followed by the second level of $78 \%$, while the first level is $75 \%$, and the third level is $73.25 \%$. Overall, the average of the aspect or dimension of selfmanagement is $76.86 \%$. That is, the percentage of selfmanagement aspects of PGSD students at the University of Kuningan are in the very good category. The high percentage of self-management aspects of PGSD level IV students is because respondents are very good at controlling themselves. This was accounted for by the results of interviews with MD year IV student respondents who showed the ability to control themselves when getting a problem in the lecture when getting a low grade, "Yes, I feel frustrated but I also improve by doing self-reflection of what is lacking from me, whether from the way of learning or the other. Then the frustration that I used to experience is just a glance; usually, I get rid of the frustration of going to the mall or playing anywhere. " The result of this interview show that MD respondents have very good selfcontrol ability, this is shown by the respondent when he gets a bad score he fixes it by doing self-reflection and trying to eliminate his sense of frustration by window shopping.

The percentage of the academic dimension or aspect of PGSD year IV students is the largest percentage, namely $87.76 \%$, followed by level II at $85.4 \%$, medium level I at $85 \%$, and level III at $84 \%$. Overall the average of the academic aspects or dimensions is $85.95 \%$. That is, the percentage of academic aspect of PGSD students at the University of Kuningan is in the very good category. The high percentage of academic aspects of PGSD level IV students is because respondents can follow the campus academic situation in each subject. This is evidenced by the results of interviews with MD respondents of level IV students who showed a willingness to follow all the academic rules set by the PGSD study program. "I can follow the academic situation of the study program which requires wearing proper clothes and not using jeans because my style is not wearing jeans and a shirt. And I am grateful to be in the PGSD Study Program because it is different from other study programs from the way they look to be neat, etc." The result of this interview shows that MD respondent can follow all the academic situations of the study program which requires a neat appearance and polite behavior. Also, respondents feel grateful for the academic situation of the PGSD study program.

The percentage of students' PGSD year IV dimension or aspect of compliance is the largest percentage of $69.65 \%$, followed by level III at $68.67 \%$, while level II is $68 \%$, and level $\mathrm{I}$ is $61.11 \%$. Overall, the average aspect or dimension of compliance is $67.91 \%$. That is, the percentage of compliance aspect of PGSD students at Kuningan University is in a good category. The high percentage of compliance aspects of PGSD level IV students is because respondents can comply with the agreement in the class assignment group. This is proven by the results of interviews with MD level IV student respondents who showed compliance when making decisions in study groups when lecturing, "I obeyed every agreement in the group, the most important thing was an agreement." The result of this interview showed that MD respondents were able to comply with all agreements that exist in the group, with a record of the results of the decision is the result of a group decision.

The percentage of assertion dimension or aspect of year IV PGSD students is the highest percentage, $69.65 \%$, followed by level III at $68.67 \%$, while level II is $68 \%$, and level I is $61.11 \%$. Overall the average of the aspect or dimension of assertion is $67.91 \%$. That is, the percentage of an aspect of assertion of PGSD students at the University of Kuningan is in a good category. The high percentage of aspects of assertion level IV PGSD students is caused by respondents being able to become activists in social activities on campus. This is shown by the result of interviews with MD respondents of fourth-year students who showed a desire to move students' friends to contribute to social activities. "I was able to move in social activities, for example, I invited my friends at that time to make blood donations." This interview shows that MD respondents can move other students to contribute to social activities. One example is in blood donor activities.

Data on the level of social skills of PGSD students at the University of Kuningan were also supported by interviews with student respondents where each level was taken by a sample of respondents to be questioned about the level of social skills from various aspects. Results from aspects of peer relations are as follows:

- Most students have a sense of empathy for other students.

- The relationship between students in learning activities is shown by inviting and reminding other students.

- Almost all students have a good relationship with other students.

The results of the analysis from the aspect of selfmanagement are as follows:

- Most students can control themselves when facing problems by introspecting themselves.

- Some students sometimes ask for advice from others as a reflection of the mistakes that have been made so as not to repeat.

The following are the results of the analysis of the academic aspects listed below:

- Most students can follow the academic situation in the PGSD study program.

- Most students can adjust to the agreed rules of each subject applied by several PGSD lecturers.

- Most students are not burdened with the academic situation of the PGSD study program.

The following are the results of the analysis of the compliance aspects summarized below: 
- Some students can comply with all agreements in the group assignment according to group decisions.

- Complying with group agreements is still based on compulsion.

The following are the results of the analysis of the assertion aspects listed below:

- Some students can become activists in social activities on campus.

- Some students will invite classmates to take part in campus social activities.

A number of these findings explain that the higher the age level of individuals in adolescent times the higher the level of social skills of an individual. The top social skills of a person are strongly influenced by family and the environment. It is clear that the educational environment, in this case, the PGSD Study Program FKIP Kuningan University as a place of research respondents to take education must be able to create an academic situation that can support the presenting of high social skills in the framework of network development and communication skills that have an impact on student output.

\section{CONCLUSION}

Based on the results of survey research that has been carried out on the level of achievement of social skills of PGSD students of FKIP Kuningan University during adolescent, it can be concluded as follows: (1) Percentage of aspects of peer relations amounted to $66.63 \%$, aspects of self- management amounted to $76.86 \%$, academic elements which had the highest percentage of $82.95 \%$, aspects of compliance reached $67.91 \%$, and assertion aspect was at number $52,48 \%$. The overall percentage of the four aspects of social skills of the students of the University of Kuningan PGSD is in the excellent category with a percentage of $69.96 \%$, and (2) Percentage of results per academic level, starting from level I at $66.20 \%$, level II at $70.76 \%$, level III at $67.76 \%$, and level IV reaching $73.69 \%$. The overall percentage of the four academic levels in social skills of the students of the University of Kuningan PGSD is in the good category with a percentage of $69.60 \%$.

\section{REFERENCES}

[1] B. Triling and C. Fadel, 21st Century Skills, Learning for Life in Our Times, San Francisco: Jossey-Bass, 2009.

[2] A. A. Hasmori, H. Sarju, I. S. Norihan, R. Hamzah, and M. S. Saud, "Pendidikan, Kurikulum, dan Masyarakat: Satu Integrasi," J. Edupres, vol. 1, pp. 350-356, 2011.

[3] P. A. Perdani, "Peningkatan Keterampilan Sosial Melalui Metode Bermain Permainan Tradisional pada Anak TK B," J. Pendidik. Usia Dini, vol. 7, no. 2, 2013.

[4] Cartledge and Milburn, Teaching Social Skills to Children, 2nd ed. New York: Pegamon, 1986.

[5] Bruce, Marsha, and Jarolimek, Social Studies in Elementary Education, 9th ed. New York: Macmillan Publishing, Co.Ltd, 1993.

[6] Sugiyono, Metode Penelitian Pendidikan Pendekatan Kuantitatif, Kualitiatif, dan R\&D. Bandung: Alfabeta, 2009.

[7] J. W. Creswell, Research Design Qualitative, Quantitative, and Mixed Methods Approaches. USA: SAGE Publications, Inc., 2014. 